\title{
A new dawn for chironomids in freshwater biomonitoring?
}

Non-biting midges are extraordinarily well-suited as environmental indicators in freshwater biomonitoring; numerous studies by those in our community support this claim. Nevertheless, our favorite organisms are excluded from many national monitoring programs due to their complex taxonomy, insufficiently described immatures, and resource demanding identification. For example, only a handful of European countries regularly use chironomid species in classification of water body ecological status for the EU Water Framework Directive (Weigand et al. 2019, supplement 2).

The use of molecular tools in species identification, especially DNA barcoding, is likely to change this. Numerous papers have shown that chironomids (as well as most other freshwater macroinvertebrates) can reliably be identified to species by DNA barcoding given that there is a high-quality barcode reference library. There are a few exceptions, like recently evolved species and species influenced by horizontal gene transfer (hybridization), where DNA barcoding does not work satisfactorily. But such cases are much less common in aquatic than terrestrial taxa where the endosymbiont Wolbachia complicates the genetic relationship between populations of closely related species (Smith et al. 2012). Of greater importance for freshwater biomonitoring might be that species previously regarded to be eurytopic actually consist of distinct genetic lineages that have different habitat preferences (Beermann et al. 2018). The ability to recognize and genetically identify cryptic species with potentially different environmental preferences can increase the resolution in biological monitoring, especially with species rich and widely distributed taxa such as Chironomidae.

DNA metabarcoding makes it possible to sequence and identify hundreds of species from bulk- or environmental samples at the same time. Thus, the time-consuming process of sorting and morphologically identifying specimens from benthic samples can be reduced, and more localities surveyed. This may also enable more biological replicates to be taken, thereby increasing the statistical power in biological assessments. Our knowledge as biologists and chironomid experts will still be needed to interpret results and detect errors, because a list of species names is of limited value if it is not proofed and put into an ecological context. Our expertise is also needed to improve existing quality metrics (indices) by incorporating chironomid data, describe the diversity, and to curate the barcode reference library.

Although progress has been made in recent years, DNA metabarcoding, for several reasons, does not provide reliable data on species abundances (Elbrecht and Leese 2015). Thus, if DNA metabarcoding is to be used regularly in freshwater biomonitoring, water quality indices that rely on presence/absence data must be preferred. Although a transfer to presence/absence data might not result in changed ecological state classifications (Buchner et al. 2019), there is room for improvement in the indices used. The obvious way would be to incorporate more species-level information on species-rich indicator taxa and thereby increase the resolution and explanatory power. Chironomidae is here the excellent group of choice for freshwater biological monitoring (Czechowski et al. 2020).

\section{Torbjørn Ekrem}

Department of Natural History, NTNU University Museum, Norwegian University of Science and Technology,NO-7491Trondheim, Norway.E-mail: torbjorn.ekrem@ntnu.no

\section{References}

Beermann, A.J., Zizka, V.M.A., Elbrecht, V., Baranov, V. and Leese, F. 2018. DNA metabarcoding reveals the complex and hidden responses of chironomids to multiple stressors. - Environmental Sciences Europe 30: 26. DOI: https://doi.org/10.1186/s12302-018-0157-x

Buchner, D., Beermann, A.J., Laini, A., Rolauffs, P., Vitecek, S., Hering, D. and Leese, F. 2019. Analysis of 13,312 benthic invertebrate samples from German streams reveals minor deviations in ecological status class between abundance and presence/absence data. - PLoS One 14: e0226547. DOI: https://doi. org/10.1371/journal.pone.0226547

Czechowski, P., Stevens, M.I., Madden, C. and Weinstein, P. 2020 (2019). Steps towards a more efficient use of chironomids as bioindicators for freshwater bioassessment: Exploiting eDNA and other genetic 
tools. - Ecological Indicators 110: 105868. DOI: https://doi.org/10.1016/j.ecolind.2019.105868

Elbrecht, V. and Leese, F. 2015. Can DNA-based ecosystem assessments quantify species abundance? Testing primer bias and biomass - sequence relationships with an innovative metabarcoding protocol. PLoS One 10: e0130324. DOI: https://doi.org/10.1371/journal.pone.0130324

Smith, M.A., Bertrand, C., Crosby, K., Eveleigh, E.S., Fernandez-Triana, J., Fisher, B.L., Gibbs, J., Hajibabaei, M., Hallwachs, W., Hind, K., Hrcek, J., Huang, D.W., Janda, M., Janzen, D.H., Li, Y., Miller, S.E., Packer, L., Quicke, D., Ratnasingham, S., Rodriguez, J., Rougerie, R., Shaw, M.R., Sheffield, C., Stahlhut, J.K., Steinke, D., Whitfield, J., Wood, M., Zhou, X. 2012. Wolbachia and DNA barcoding insects: patterns, potential, and problems. - PLoS One 7(5):e36514. DOI: https://doi.org/10.1371/journal. pone. 0036514

Weigand, H., Beermann, A.J., Čiampor, F., Costa, F.O., Csabai, Z., Duarte, S., Geiger, M.F., Grabowski, M., Rimet, F., Rulik, B., Strand, M., Szucsich, N., Weigand, A.M., Willassen, E., Wyler, S.A., Bouchez, A., Borja, A., Čiamporová-Zatovičová, Z., Ferreira, S., Dijkstra, K.-D.B., Eisendle, U., Freyhof, J., Gadawski, P., Graf, W., Haegerbaeumer, A., van der Hoorn, B.B., Japoshvili, B., Keresztes, L., Keskin, E., Leese, F., Macher, J.N., Mamos, T., Paz, G., Pešić, V., Pfannkuchen, D.M., Pfannkuchen, M.A., Price, B.W., Rinkevich, B., Teixeira, M.A.L., Várbíró, G. and Ekrem, T. 2019. DNA barcode reference libraries for the monitoring of aquatic biota in Europe: Gap-analysis and recommendations for future work. - Science of The Total Environment 678: 499-524. DOI: https://doi.org/10.1016/j.scitotenv.2019.04.247 